УДК 811.163.41.09 Грим, J.

811.163.41.09 Караџић, В. С.

https://doi.org/10.18485/msc50.2019.1.ch6

Манфред Јенихен

\title{
САРАДЊА ВУКА КАРАЏИЋА И ЈАКОБА ГРИМА - ЈЕДНА ТРАДИЦИЈА КОЈА ОБАВЕЗУЈЕ
}

Драге колегинице и колеге,

Тешко је, после несумњиво најбољег познаваоца односа̂ између Вука Караџића и Јакоба Грима, поштованог колеге проф. Миљана Мојашевића, и његовог врло одмереног излагања, рећи нешто значајно и ново о овој теми. Ипак ћу покушати да кажем неколико мисли о традицији ове примерне сарадње двојице великана наших народа на једној историјској прекретници - и то под аспектом културнополитичких претпоставки и културнополитичког дејства ове сарадње која и за нас данас представља обавезу.

Дозволићете ми, с обзиром на радни карактер симпозијума, а и да бих скратио излагање, да своја размишљања изнесем у облику теза.

1. Многострано Караџићево дело - општепознато овом скупу, те је стога непотребно поново се враћати појединостима - имало је револуционарни значај за српску културу. Борба за признавање „свињарског и говедарског језика"1 отвара српском народу могућност да добије улазницу у друштво просвећених нација. Сакупљање народних песама (,јуна-чке пјесме" и др.) и њихово презентирање у форми у којој их је народни певач створио, учинило је да се овом делу народне традиције призна статус дела националне и опште културе. И без неког за оно време утопи-стичког програма општенародног просвећивања, створене су на тај начин битне претпоставке за остварење народног и културног јединства.

Вукова борба за народни језик и поезију оријентисала се на - у смислу Лењина - другу, демократску културуํ․ Захваљујући њему и његовом делу, она је постала привремено доминантном на једној значајној

${ }^{1}$ Исп., J. Grimm, Vorrede: Wuk's Stephanowitsch Kleine serbische Grammatik, Leipzig - Berlin 1824, стр. XII и сл.

${ }^{2}$ Исп., V. Lenin, Kritische Bemerkungen zur nationalen Frage; Werke, Bd. 20, Berlin, 17. 
прекретници историјског препорода. Као таква, она је добила конститутивну улогу у формирању српске националне свести. У епохи српског романтизма достигнута је на тај начин права повезаност народне и националне културе. Тиме су ојачани демократски елементи у даљем току развитка.

Вуков рад наилазио је на јак отпор веома агилних противника, чак и на међународном плану (у Русији, Аустрији и Немачкој), моћних и у политици и у култури, који су се залагали за конзервативан однос према традицији. У таквим условима, његово дело наишло је на признање тек уз интернационалну помоћ. Ефикасна подршка подразумевала је, међутим, сличне или истоветне демократске концепције у науци и друштву. У датим околностима ова подршка морала је имати културне и политичке последице.

2. Та међународна помоћ долазила је, поред Копитара, нарочито ефикасно од стране Ј. Грима. Као једна од водећих личности немачке касноромантичарске науке ${ }^{3}$, Грим се овде врло живо ангажује. Пошто му је Копитар 1815. у Бечу скренуо пажњу на Вуков рад ${ }^{4}$, д деценији после те године која је одлучујућа за Вуково формирање, Грим је Вуку пружао разноврсну подршку. На другој страни, Вуковом стварању он дугује многе сугестије за сопствена научна истраживања (о епу, о „натурпоезији”, о историјско-компаративним истраживањима језика итд. $)^{5}$

Гримова ангажованост за признавање Вукова дела у Немачкој обухвата - изузев савремене - сва најзначајнија подручја:

- $\quad$ непосредни подстицај нпр. за сакупљање народних песама (исп. циркулар од 1815), ${ }^{6}$ наговарање да изда своје народне песме; ${ }^{7}$

- рецензије и чланци посвећени Вуковим збиркама народних песама још од Пјеснарице, који су утицали да јужнословенске народне песме добију високо признање;

${ }^{3}$ Исп., W. Neumann - В. Löther Gedanken zur bevorstehenden Ehrung Jacob Grimms: 1963; Weimarer Beiträge, Берлин 1963, 469. и д.

${ }^{4}$ Подробније исп., М. Vasmer, B. Kopitars Briefwechsel mit Jacob Grimm: Berlin 1938, посебно IX и д.

${ }^{5}$ Најновије о томе исп., М. Мојашевић, Вук и Немци: Немачко-југословенске културне везе, Београд 1974, 9. и д.

${ }^{6}$ Исп., Вукова преписка II, Београд 1908, 1. и д. (писмо од 2. IV 1815). Најновије о томе исп., М. Мојашевић, Гримово изиркуларно бечко писмо: Научни састанак слависта..., 2, Београд 1972, 163. и д.

7 Вукова преписка II, 65. (писмо од 10. VII 1853). 
- $\quad$ преводи народних песама сачињени према идеалу романтичарског превођења

- рецензија Вукова Рјечника и истицање значаја народног језика за књижевни језик';

- радикална прерада неуспелог превода Мале српске граматике који је сачинио Тирол, као и научно, културно и политички значајан предговор ${ }^{10}$;

- напори да издејствују Вуково научно и лично признање у тадашњој Немачкој; нпр. препорука Гетеу, пријем у Гетингенско учено друштво, а касније - чланство у берлинској Академији, додела пруског Ордена црквеног орла итд. ${ }^{11}$;

- $\quad$ његово заузимање за штампање превода Новог завјета ${ }^{12}$.

Недостајала је једино актуелна српска историја онога времена, коју, међутим, Ранке „ех oro Vukii” 1829. представља Немцима.

Помоћ Вуку имала је одлучујући значај у првој половини двадесетих година. Караџић је - и у томе није на последњем месту његова промоција у Јени 1832. - добио значајно признање у немачкој касноромантичарској науци и култури. С обзиром на тадашњи положај немачке науке у европским размерама, ово признање имало је високу вредност и повратно дејство на српско друштво.

3. Гримово залагање за Караџића као и за језик и културу Срба било је саставни део његовог изузетно обимног научног дела које се одликовало непосредном друштвеном револуиионарношћу. Прихватање Вукова дела код Грима засновано је на демократској научној концепиији према којој је он просуђивао о вредностима народне културе, полазећи од историјско-компаративног посматрања језика. ${ }^{13}$ Ова концепција, каракте-

${ }^{8}$ Овим принципима исп., М. Jähnichen, Zur Frage der Übersetzungstheorie und praxis zur Zeit der Romantik: Zeitschrift für Slawistik XVII, Berlin 1973, 110 и д.

${ }_{9}$ Исп., Н. Peukert, Deutsch-serbische literariche Wechselseitigkeit in der VukStefanović-Karadžić-Generation: Vuk Stefanović Karadžić, Universitätsreden, HalleWittenberg 1965, 32. и д.

${ }^{10}$ Исп. између осталог, Н. Peukert, О значају Јакоба Грима за Вукову кониепцију књижевног језика: Научни састанак слависта... 2, 147. и д.

11 M. Vesmer, изит. д., VII и д.

${ }_{12}$ Исп., M. Vasmer, Bausteine zur Geschichte der deutschslavischen geistigen Beziehungen, Berlin 1939, XVI.

${ }_{13}$ Исп., W. Bondzio - Е. Arndt, Zur Einführung. Bemerkungen zur Jacob-Grimm Konferenz an der Berliner Humboldt-Universität: Wissenschaftliche Zeitscrift der Humbolodt-Universität Berlin, Gesellschafts- und sprachwissenschaftliche Reihe, Jg. XIV, Berlin 1965, 443 и д. 
ристична за прогресивно крило немачке романтике, у вези је са схватањем да је један од кључних задатака: посматрајући историјски развој језика пробудити разумевање за напредак народа и посебно за његову културу.

Са̂м Грим је настављао напредне традиције немачког просветитељства и класике. Заједно са својим братом Вилхелмом он је за време француске окупације под Наполеоном - истраживање немачког језика и књижевности схватао као „еine unsichtbare schirmende Waffe gegen feindlichen Uebermut”. При томе је у центру његове пажње традиционално родовско друштво, те је самим тим одбацивао конзервативну мистификацију средњег века, која је карактеристична за један други део немачке романтике.

У патријархалном друштву он је открио вредности народне културе. То је била „натурална поезија”, непосредни израз утопијски идеализираног погледа на рану историју нације ${ }^{14}$. Наглашавајући повезаност народне историје са историјом језика и књижевности, он ју је карактерисао као високо информативни критериј о праскозорју и првој младости једне нације. ${ }^{15}$ Грим се, додуше, оријентисао на истраживање језика и поезије, а тиме и историје немачког народа, односно германских племена̂, али се на томе није заустављао. У смислу Гетеових концепција светске литературе, које је овај формулисао двадесетих година прошлог века, и тежње немачке романтике за универзалношћу, ослањајући се на Хердеров хуманистички идеал, Грим на исти начин вреднује језик и културе других народа.

Словенски народи, који су у Наполеоновим ратовима ступили на европску историјску сцену, имали су за Грима посебан значај. Њихов национални препород и њихова заокупљеност језицима и културама, нпр. у смислу „Institutiones...” Добровскога, пружили су му потребан материјал за историјско-компаративне студије. ${ }^{16}$ Пошто му је Копитар скренуо пажњу на Вука и његову борбу за афирмацију књижевног језика створеног на народној основици, ово за њега добија егземпларни значај.

4. У језику Срба („Serbisch” у смислу Гримова „поново уобичајеног могућег проширења појма” $)^{17}$ он је наишао на оно што је у свом гетингенском говору „Rede über Geschichte und Poesie” назвао »ein gevisses

${ }^{14}$ Исп., W. Thalheim, Naturpoesie und Kunstpoesie bei den Brüdern Grimm: Weimarer Beiträge, Berlin 1963, 294. и д.

${ }^{15}$ Исп., J. Grimm, Rede über Geschichte und Poesie: Kleinere Schriften 1, Berlin 1881, 497. и д.

${ }_{16}$ Исп., М. Vasmer, Briefwechsel..., VII и д.

17 J. Grimm, Vorreden..., 1 ц. 
sicher schreibendes Naturgefühl«, »das ein Volk in der frischen Jugendzeit zu begleiten pflegt «"

Језик је открио »eine bisher völlig unbekannte Schönheit und Reichhaltigkeit. ${ }^{19}$ За њега је он био „еine wort- und formreiche bildsame und edle Sprarhe ${ }^{20}{ }^{20}$ »eine sanfte, überaus sangbare Sprache $\aleph^{21}$, $» j e n e$ slawische Sprache..., die sich vor anderem durch ihre Lauterkeit und Schönheit, wie sich seit Herrn Wuks Bemühen hinzusetzen lässt, durch ihre anziehenden Denkmäler «22 - нарочито препоручује Немцу као захвалан материјал за учење.

Књижевност тога народа, дакле народна поезија чини „, herrlichste Naturpoesien, dergleichen kein anderer slawischer Volksstamm aufzuweisen und dem sich selbst das beste, was deutsche Völker an Volksliedern besitzen, an Süssigkeit, Unschuld und Anmut kaum vergleichen lässt”23. То су по Гриму „reine ungehemmte Stimmen echter Volkspoesie wofern es ihrer irgend gegeben hat"24 лирске песме њихове „auf der Grenze des Morgen- und Abendlandes entsprungen, die Vorteile orientalischer und oksidentalischer Lyrik vereinigen"25

Вредности ове врсте биле су највиши критерији романтике. Са гласно романтичарском поистовећењу језика и мишљења, а према схватању да особености језика једног народа и карактер његове поезије представљају основу за закључивање о карактеру са̂мога народа, неизбежна је била изразито позитивна оцена тако оквалификоване српске нације: ${ }^{26}$ „Wenn nun behauptet warden darf, dass in der Volksdichtung der Atem einer jeden Sprache ungehemmt und frei zu spüren sei, so wird die Folgerung gar nicht befremden: aus diesen verdienstvollen Sammlungen könne der wahre Geist der slawischen Sprache, Poesie und der ganzen Natur dieser Völker treuer studiert und geschöpft werden, als selbst aus den Erzeugnissen der später gebildeten polnischen, böhmischen und russischen Literatur". ${ }^{27}$

18 J. Grimm, Rede über Geschichte und Poesie, цит., 497. и д.

19 J. Грим у својој рецензији на Рјечник: Göttinger Gelehrte Anzeigen 1819, 569. и д.

${ }^{20}$ J. Grimm, Vorrede..., XIV.

${ }^{21}$ Ј. Грим, рецензија на Пјеснарииу: Wiener Allgemeine Zeitung 1815, № 74, 1180.

22 J. Грим, рецензија на Вукову књигу, Народне njecмe, Gött, Gelehrte Anzeigen $1823,1173$.

23 Ј. Грим у рецензији на Рјечник, иит. д., 570.

24 J. Грим у рецензији на трећу књигу Народних пјесама, изт., 1761.

25 J. Грим у рецензији на прву и другу свеску, Gött. Gelehrte Anzeigen 1824, 809. и сл.

${ }^{26}$ Исп., В. Löther, Philolog der Nation. Zum Zusammenhang von Sprachgeschichte und Volksgeschichte bei J. Grimm: Wiss. Zeitschr. der НuВ..., цит., 463. и д.

27 Ј. Грим у рецензији на Рјечник.., изт. д., 569, и д. 
5. И за Грима и за Вука било је карактеристично да су своје научне циљеве усмеравали према друштвеним потребама. Тако се у Гримовом настављању прогресивне традиције немачког просветитељства и класике испољавало јединство науке и друштва, исто као што је и Караџић био оличење прогресивне и борбене романтике, уперене против конзервативне традиције. У условима под којима се Караџић борио за народни језик, његово је залагање, исто као и Гримова ангажованост, морало имати непосредне друштвене и културнополитичке последице. Обојица су били свесни тога: тако је у писму Лахману од 30. XI 1823. Грим писао: „Es wurde auch in serb. Liedern gelesen..., eine Recension davon geschrieben und abgeschickt, welche Vuk (nicht des Lobes wegen, sondern aus politischen Gründen, weil sich Gegner in Wien, Ungarn und Serbien selbst seinem möglichen Eifer widersetzen) wünschte." 28

Грим је свом снагом своје учености чинио потпору политичком аспекту његовог рада. У рецензији Рјечника, издатој 1819., у јасно формулисаној полемици против српског свештенства, које чак отворено апострофира, Грим између осталог пише: „Wen man den Serben Serbisch zu schreiben verbieten und Slawenisch (Altslawisch) zu srhreiben gebieten wollte, so wäre das ebenso viel, als die Dänen heutzutage der isländischen Grammatik zu folgen gezuwungen wären... Und die serbische Sprache ist ungleich vollkomner geblieben, als die dänische, wenn man sie mit dem Altertume vergleichen wollte..." ${ }^{29}$

У свом познатом предговору ,Малој српској граматици' Грим наводи сличне друштвено-политичке аргументе: „Die Geistlichkeit und die meisten, welche in Serbien den Wissenschaften obliegen, haben den seltsamen Wahn gefasst, dass ihre angeborene Landessprache welcher sie gleichwohl tagtäglich pflegen, nichts als ein aus der Cyrillischen Kirchensprache entstelltes, durch türkische Worte vollends verderbtes Idiom sey, das man billig gemeinen Hirten und Bauern überrlasse. Dieses Vorurteil beruht theils auf einer oberflächlichen Kenntniss beider sowohl der altslavischen als der serbischen Mundart, theils auf Völligem Verkennen dessen, was todte und lebendige Sprachen seyn können und sollen" ${ }^{\text {30 }}$.

На овај начин Грим се непосредно и свесно умешао у актуелне политичке догађаје. Као и касније у протесту против самовоље хановерског

${ }_{28}$ Исп., I. Mahnken, Vuk, Vuks Gegner und Göttingen: Вуков зборник, Београд 1966, 543. и д., нарочито 563.

29 J. Грим, cit., d., 569. и д.

30 J. Грим, Vorrede..., XII и сл. 
краља ${ }^{31}$, Грим се и у научном деловању и у сарадњи с Вуком одликовао јасним реалистичким односом према стварности, и необоривим судовима једног демократе.

Ово је било од знатног утицаја на тадашњу српску јавност. То је врло јасно формулисано у једном Вуковом писму Гриму од 18. новембра 1824, у којем се захваљује на рецензији: „Wahrhaftig, auch die Feinde unserer Sprache lesen gerne solche Sachen und bekehren sich" ${ }^{32}$

6. С обзиром на Гримов истакнути положај у немачкој науци који је стекао већ 1820, његови су ставови имали велики значај. Они су у великој мери допринели буђењу интересовања за Србију у Немачкој, и бар привременом распламсавању тога интересовања у одушевљење. Средином двадесетих година може се тако cum grano salis говорити о „српској етапи".

Објективно посматрано, стимулативну улогу при томе имају:

- дуготрајно зрачење Хердерових хуманитарних идеала;

- конкретна политичка ситуација на Балкану, а посебно ослободилачке борбе Грка;

- $\quad$ интересовање Европе за народну поезију, за њено откривање и упознавање у аутентичној форми као што ју је презентирао Вук за разлику од својих претходника, међу којима је и Качић;

- $\quad$ естетски узор у Хомеровим еповима и истраживања епа;

- Гетеова концепција о светској литератури ${ }^{33}$.

Грим се свесно ослања на ове објективне моменте, у сагласности са својим реалним схватањима, и залаже се за језик и културу Срба. Ово потврђују и одабрани термини које смо више цитирали.

7. На тај начин је у свест немачке касноромантичарске науке и културе, коју је у великој мери припремио и уобличио Грим, продро језик, књижевност („Naturpoesie”) и историја Срба, и били изузетно позитивно оцењивани. Срби су сматрани слободољубивим народом, јер њихова народна поезија, као што вели Грим у једној рецензији од 1823. године, опева „Tapferkeit und kühnen Mut, Treue, die Gewalt edler Gesinnung von Freund und Feinden". На изградњу једне прогресивне представе о Јужним Словенима (посебно Србима) у Немачкој посебан утицај су имали Гри-

31 J. Грим, Ueber meine Entlassung, Basel 1838, passim.

32 Цит. према Вуковој преписиз, изит. д., 48.

33 Подробније исп., М. Jähnichen, Zum Anteil der Literaturrezeption bei der Formung des deutschen und österreichischen Südslavenbildes in 19. Jh., Teil 1: 1.800-1.860: ZfSl XVI, Berlin 1971, 221. и д. 
мови ставови. У истој мери у којој су деловали у ширину, ови ставови су захватали и у дубину.

На другој страни, на најпозитивнију оцену и високо поштовање Гримов рад наилази прво код Вука и Копитара, а за њима у томе касније полази и целокупна српска јавност. Ово је сажето у следећој Вуковој формулацији из двадесетих година: „Sie sind das gröste Glück unserer Lieder, unserer Sprache und unserer Literatur" ${ }^{\prime 4}$. Тиме су немачко име и немачка нација наишли на изразито позитиван одзив у Срба. А Грим је, захваљујући својој несебичној помоћи Вуку и узорном сарадњом са Вуком, представљао пример који је деловао у оба правца.

8. Можемо резимирати. Сарадња Вука и Грима, коју смо овде у тезама приказали са културнополитичког гледишта, и њени резултати, обавезују нас у вишеструком погледу.

a) Ова сарадња је достигнуће засновано на прогресивним идејама оног доба. При том су полазне позиције, узимајући у обзир конкретне друштвено-историјске услове, веома различите у Србији и Немачкој. Грим је могао следити прогресивну традицију немачког просветитељства и свесно је настављати само имајући пред очима циљеве немачке романтике. Вук је морао бескомпромисно да се бори против дотадашње традиције званичне српске књижевности. Тако је деловање једног означавало континуитет, а другог било у дисконтинуитету са домаћом традицијом. Они се сусрећу на основи демократске концепције о значају језика и културе народа.

б) Сарадња се заснива на демократској и научној концепцији, а сем тога се формира под дејством субјективних фактора - узајамних симпатија њих обојице. У тим условима демократска схватања науке добила су јаку културнополитичку, односно друштвено-политичку релеванцију са актуелним политичким значајем.

в) Из ове сарадње израсло је у Немачкој прве половине XIX века високо поштовање за Србе и њихову културу ${ }^{35}$, а у Србији за Немце и њихову културу ${ }^{36}$. На значајној прекретници националног развоја и узајамних односа обеју нација, сарадња Вука и Грима имала је одлучујућу улогу.

г) Ово узајамно поштовање имало је дубоке корене. Зато је и могло тако дуго опстати, и чак преживети она времена када су односи двеју

34 Вукова преписка, цит., 12. (писмо од 14. XI 1823).

35 Подробније исп., М. Jähnichen, Vuks Bedeutung bei der Formung des deutschen Südslavenbildes im Spiegel der zeitgenössischen deutschen Presse: Anali Filološkog fakulteta 4, Београд 1964, 185. и д.

36 Исп., М. Mojašević, Jacob Grimm und die Jugoslawen: Deutsch-jugo slawische Begegnungen, Wien 1970, 37. и д. 
нација озбиљно помућени политичким антагонизмом немачке и српске буржоазије, који су почели да оптерећују те односе у другој половини XIX века.

д) У наше доба и у нашој социјалистичкој епоси ова сарадња Грима и Вука јесте традиција која нас обавезује, пре свега као традиција по себи, а и као традиција коју смо дужни да у данашњим условима даље негујемо и продубљујемо. И овај симпозијум је, по моме дубоком убеђењу, израз свега тога.

(Превод с немачког: Brigitte Simić)

\section{M[anfred] Jähnichen \\ DIE ZUSAMMENARBEIT VON VUK KARADŽIĆ UND JACOB GRIMM - EINE VERPFLICH- TENDE TRADITION}

\section{Zusammenfassung}

Der Beitrag betrachtet die Beziehungen zwischen Karadžić und Grimm vornehmlich unter dem Aspekt ihrer kulturpolitischen Voraussetzungen und Auswirkungen. Karadžić' Kampf um die Volkssprache war auf eine demokratische Kultur orientiert und damit revolutionär. Dass seine progressiven Bestrebungen von Grimm unterstützt wurden, beweist die Ähnlichkeit ihrer Anschauungen über Wissenschaft und Gesellschaft. Erwähnt wird Grimms vielfältige Unterstützung für Karadžić und sein Werk, die zu seiner wissenschaftlichen und gesellschaftlichen Anerkennung in Deutschland und über seine Grenzen hinaus beigetragen hat. Grimms Begeisterung für die serbische Sprache und Volkspoesie geht dabei über die der Romantiker hinaus, bleibt nicht bei deren Idealisierung stehen, sondern verkörpert die progressive, kämpferische Romantik.

Die Zusammenarbeit zwischen Karadžić und Grimm beruhte auf den fortschrittlichen Ideen ihrer Zeit und einer demokratischen Gesellschafts- und Wissenschaftskonzeption. Sie tat viel dazu, dass sich bei den Deutsche ein fortschrittliches Südslawenbild entwickelte. Auch in umgekehrter Richtung war das der Fall. Damit stellt ihre Zusammenarbeit für uns heute eine verpflichtende Tradition dar. 